\title{
Stimulation of erythropoietin in renal insufficiency by hypobaric hypoxia
}

\author{
J. Quick, A. Eichenberger, and U. Binswanger \\ Section of Nephrology, University Hospital, Zurich, Switzerland
}

\begin{abstract}
Patients with renal anaemia show inadequate levels of immunoreactive erythropoietin (Epo) related to the degree of anaemia. The purpose of our study is to compare the degree of stimulation of Epo by means of hypobaric hypoxia in normal controls and patients with renal anaemia. Baseline Epo concentrations were found to be $11.1 \pm 2.0 \mathrm{U} / 1$ in 10 healthy volunteers and $11.4 \pm 4.6 \mathrm{U} / 1$ in six patients with renal anaemia. After exposure to hypobaric hypoxia equivalent to $4560 \mathrm{~m}$ above sea level for a duration of $3.5 \mathrm{~h}$, we observed a significant increase in serum Epo in healthy volunteers to $22.8 \pm 9.1 \mathrm{U} / 1$ $(P<0.005)$, while there was no increase in patients with renal anaemia: $12.3 \pm 5.2 \mathrm{U} / 1(P<0.2)$.

Our results show that in patients with renal anaemia serum Epo concentrations are comparable to those of normal controls, but inadequate in view of the concomitant degree of anaemia. Stimulation by acute hypobaric hypoxia was not possible in patients with renal insufficiency as opposed to normal controls. From these data it can be concluded that either Epo production is working at maximum capacity under baseline conditions, or an additional hybobaric stimulus is not able to influence a disturbed set point of the oxygen sensor regulating Epo synthesis.
\end{abstract}

Key words: erythropoietin; hypobaric hypoxia; renal insufficiency

Correspondence and offprint requests 10: Professor Dr med U. Binsuanger. Section of Nephrology. Department of Internal Medıane, Lnversity Hospıla1, Rämistr. 100, CH-809! Zünch.

\section{Introduction}

The first author to describe the coincidence between chronic renal failure and anaemia was $\mathbf{R}$. Bright more than a hundred years ago. It was not until 1906 that Carnot and Deflandre [1] assumed a humoral factor to be responsible for the stimulation of erythropoiesis. The chemical structure of this factor remained elusive for many decades until Miyake et al. were able to purify the glycoprotein erythropoietin (Epo) [2]. Since Jacobs et al. [3] successfully cloned Epo in 1985, we have come to know its exact chemical structure, which contains 166 amino acids with a peptide molecular weight of $18 \mathrm{kDa}$ and a carbohydrate content with three $\mathrm{N}$-glucosylation sites giving a total molecular weight of $34 \mathrm{kDa}$.

Now Epo is recognized as the most significant hormone for the regulation of the proliferation and differentiation of erythroid precursors in the bone marrow. In the adult, more than $90 \%$ of Epo is produced in the kidney and less than $10 \%$ in the liver. The exact Epo producing cell is not known at present. There is, however, evidence that in the kidney, Epo producing cells are inner cortical peritubular interstitial cells [4].

The hormone takes part in a complex and not yet fully understood feedback mechanism to regulate the red blood cell population according to physiological demands. The main stimuli for Epo production are anaemia and hypoxic hypoxia. It is well established that in individuals with non-renal anaemia, serum Epo concentration is inversely correlated with the haematocrit. In contrast, in patients with renal anaemia the serum Epo does not correspond to the degree 
of anaemia, suggesting that anaemia due to chronic renal diseases is caused by relative Epo deficiency [5-8].

Recombinant human Epo (riHuEpo) has been availabie for ciinical use since 1988 and has been administered successfully for the treatment of renal anaemia.

The present study was designed to determine the possibility of stimulating endogenous Epo production in a collective of patients suffering from renal anaemia. It has often been shown that in healthy subjects a sojourn at high altitudes increases Epo concentrations in blood and urine [9-16]. We chose to alter the duration and degree of hypobaric hypoxia, extrapolating from the data of Eckardt et al. [17] obtained in normal individuals. We measured immunoreactive serum Epo before and after exposure to hypobaric hypoxia.

\section{Subjects and methods}

\section{Patients}

One female and nine male volunteers with a mean age of 33 years (range 28-49) were chosen to form a control group. All laboratory parameters inclusive of haematocrit and creatinine values were in the normal range. Six male patients with a mean age of 47.3 years (range 29-69) suffering from chronic renal failure and renal anaemia were selected. Haematocrit was between 22.4 and $31.3 \%$, haemoglobin concentration between 7.5 and $10.3 \mathrm{~g} / \mathrm{dl}$, and creatinine values were between 545 and $1264 \mu \mathrm{mol} / \mathrm{l}$. Before decompression, we also measured other laboratory parameters such as serum urea, serum potassium, calcium, inorganic phosphate, alkaline phosphatase, serum iron, transferrin, ferritin, number of erythrocytes, reticulocytes, leukocytes, thrombocytes, total protein, and immunoreactive serum Epo concentration. No patients had parathyroidectomy; serum immunoreactive parathyroid hormone was not measured. Four patients were in predialysis stage, two patients began haemodialysis immediately preceding our study. None of them had been treated with rHuEpo or were anephric. The diagnoses were glomerulonephritis ( 3 patients), reflux nephropathy (2 patients) and diabetic nephropathy (1 patient). See Table 1 .

\section{Protocol}

The procedure was explained and well understood by all patients who agreed to join the study. The cxperiment was performed at the Center for Hyperbaric Treatment and Diving Research at the Lniversity Hospital Zürich, Switzerland. with an altitude simulation unit for altitudes up to $10000 \mathrm{~m}$. The patients were decompressed over a period of $: 5 \mathrm{~min}$ from ar. atmospieric pressire of $722 \mathrm{mmHg}$ (corresponding to an altitude of $470 \mathrm{~m}$ above sea level) to $427 \mathrm{mmHg}$ (corresponding to an altitude of $4560 \mathrm{~m}$ above sea level). All subjects remained at this decompression for $3.5 \mathrm{~h}$ followed by the recompressior, wh: hasted between 20 and $30 \mathrm{~min}$. The partial pressure of oxygen was held constant 2t $20 \%$. Tamparatire vas varied to afford comfort. Blood samples were obtained by puncture of the antecubital
Table 1. Laboratory parameters and diagnoses for the six patients with renal anaemia

\begin{tabular}{|c|c|c|c|c|c|c|}
\hline Patient no. & $1^{*}$ & 2 & 3 & $4^{*}$ & 5 & 6 \\
\hline Baseline Epo (U l) & 11.2 & 14.4 & 15.8 & 5.0 & 6.8 & 15.2 \\
\hline Diagnosis & $\mathrm{RN}$ & R.T & GN & G. & $\mathrm{DX}$ & GX \\
\hline Urea (mmol l) & 30.7 & 39.5 & 31.0 & 31.4 & 31.1 & 31.8 \\
\hline Creatinine (umol l) & 1264 & 722 & 615 & 901 & 545 & 760 \\
\hline Total protein (g l) & $7 !$ & 69 & 71 & 69 & 82 & 78 \\
\hline Potassium (mmol l) & 4.2 & 5.6 & 4.0 & 4.3 & 4.1 & 5.2 \\
\hline Calcium (mmol l) & 1.86 & 2.32 & 2.17 & 2.22 & $2.3 !$ & 2.20 \\
\hline Phosphorus (mmol l) & 1.85 & 1.41 & 2.22 & 2.04 & 1.47 & 1.47 \\
\hline Alk. Ph. (U l) & 164 & 60 & 61 & 96 & 82 & 78 \\
\hline $\mathrm{Fe}(\mu \mathrm{mol})$ & 8.6 & 10.7 & 10.6 & 17.1 & 14.4 & 11.9 \\
\hline Transferrin $(\mu \mathrm{mol} \mathrm{l})$ & 32 & 19 & 27 & 29 & 31 & 31 \\
\hline Ferritin $(\mu \mathrm{g} l)$ & 50.1 & 103 & 118 & 188 & 24.0 & 133 \\
\hline $\mathrm{Hb}(\mathrm{g} \mathrm{dl})$ & 7.5 & 9.4 & 7.7 & 8.5 & 9.4 & 10.3 \\
\hline Erythrocytes (million, $\mu$ l) & 2.52 & 3.30 & 2.36 & 2.85 & 3.16 & 3.48 \\
\hline Het $(\%)$ & 24.0 & 28.5 & 22.4 & 24.9 & 28.5 & 31.3 \\
\hline Reticulocytes (\% & 13 & 24 & 19 & 25 & 5 & 17 \\
\hline Leukocytes (mill ' $\mu \mathrm{l}$ ) & 7.66 & 8.6 & 6.3 & 6.4 & 6.4 & 7.4 \\
\hline Thrombocytes (mill $\mu \mathrm{l}$ ) & 222 & 288 & 213 & 263 & 308 & 189 \\
\hline
\end{tabular}

GN, glomerulonephritis; RN, reflux nephropathy; DN, diabetic nephropathy.

* Haemodialysis stage, all others were in predialysis stage.

vein. The first sample was drawn before entering the chamber and included all serum parameters used to confirm chronic renal failure and Epo. The second sample was taken after $3.5 \mathrm{~h}$ sojourn at high altitude, the third sample was taken $1 \mathrm{~h}$ after having left the chamber. Epo was measured with a commercially available ELISA kit (Medag, Hamburg, Germany) [18]. Blood samples were centrifuged for $10 \mathrm{~min}$ at $1000 \mathrm{~g}$ and immediately stored at a temperature of $-20 \mathrm{C}$ until Epo analysis was completed. Duplicate samples were analysed in the same assay. Statistical analysis was performed using Wilcoxon's rank test for paired and unpaired data as appropriate. Data are given as mean $\pm S D$. All other chemical and haematological parameters were measured using autoanalyser and automatic counter techniques respectively.

\section{Results}

Comparing baseline serum Epo concentrations between healthy subjects and patients, no significant difference was found. Healthy subjects' Epo values ranged from 7.4 to $15.0 \mathrm{U} / 1$ with a mean and SD of $11.1 \pm 2.0$; patients' Epo values ranged from 8 to $16 \mathrm{U} / 1$ with a mean and SD of $11.4 \pm 4.6 \mathrm{U} / 1(P=$ 0.45 ).

After a 3.5 h sojourn at high altitude we observed a mean increase of serum Epo concentration in cieaitiny persons to $22.8 \pm 9 .: \mathrm{L}$ i, showing a relative mean increase of $101 \pm 55 \%(P<0.005, t=4.6)$. See Tabie 2. Serum Epo in patients showed a mean increase to $12.3 \pm 5.2 \mathrm{U} / \mathrm{l}$, which means a relative mean increase of $7.5 \pm 14 \%(P<0.2)$, which is not statistically signit:cart. The range of relative increase in serum Epo in healthy controls was from 50 to 
Table 2. Serum Epo levels for six patients and 10 controls at baseline (a) and after $3.5 \mathrm{~h}$ of exposure (b) with relative change (ab) as compared to baseline values

\begin{tabular}{|c|c|c|c|c|c|}
\hline Patient no. & $\begin{array}{l}\text { Baseline } \\
\text { Epora) } \\
\text { (U/1) }\end{array}$ & $\begin{array}{l}\text { After } 3.5 \mathrm{~h} \\
\text { exposure(b) } \\
(\mathrm{U} / \mathrm{l})\end{array}$ & $\begin{array}{l}\text { Relative } \\
\text { change(ab) } \\
(\%)\end{array}$ & $\begin{array}{l}1 \mathrm{~h} \text { after } \\
\text { recompr.(c) } \\
(\mathrm{U} / \mathrm{l})\end{array}$ & $\begin{array}{l}\text { Relauve } \\
\text { change(ac) } \\
\text { (\%) }\end{array}$ \\
\hline 1 & 11.2 & 13.8 & +23 & 16.6 & +38 \\
\hline 2 & 14.2 & 12.8 & -11 & 12.2 & -15 \\
\hline 3 & 15.8 & 15.8 & 0 & 158 & 0 \\
\hline 4 & 5.0 & 5.4 & +8 & 10.2 & +104 \\
\hline 5 & 68 & 6.8 & 0 & 7.8 & +15 \\
\hline 6 & 152 & 19.0 & +25 & 202 & +33 \\
\hline Mean & 11.4 & 123 & +75 & 13.8 & +29 \\
\hline $\pm S D$ & 46 & 52 & 14 & 4.6 & 41 \\
\hline \multicolumn{6}{|l|}{ Control no } \\
\hline 1 & 15.0 & 375 & +150 & & \\
\hline 2 & 9.6 & 20.8 & +116 & & \\
\hline 3 & 10.7 & 20.6 & +92 & & \\
\hline 4 & 10.1 & 19.2 & +90 & & \\
\hline 5 & 7.4 & 15.4 & +108 & & \\
\hline 6 & 11.2 & 18.8 & +68 & & \\
\hline 7 & 12.8 & 42.0 & +228 & & \\
\hline 8 & 12.0 & 18.8 & +57 & & \\
\hline 9 & 11.2 & 17.0 & +52 & & \\
\hline 10 & 11.2 & 178 & +50 & & \\
\hline Mean & 111 & 228 & +101 & & \\
\hline $\pm S D$ & 2.0 & 91 & 55 & & \\
\hline
\end{tabular}

Serum Epo levels were also measured $1 \mathrm{~h}$ after leaving the chamber/recompression (c) in the patients only

$228 \%$. In contrast, the patients showed increases from -11 to $25 \%$.

These results revealed a significant difference in serum Epo after exposure to altitude between healthy subjects and renal patients $(P<0.025)$. Patient numbers were too small to detect a difference between dialysis and non-dialysis patients, nor did we find a correlation between patient's haematocrit and serum Epo before the exposure to hypobaric hypoxia. Indices of uraemia such as creatinine, urea, $\mathrm{K}, \mathrm{Ca}, \mathrm{P}$, and AP were not related to the Epo response either. Taking into account serum Epo $1 \mathrm{~h}$ after having left the decompression chamber, no statistically significant mean increase was found. Reasons for the great range of relative change in serum Epo (from -15 to $104 \%$ ) could not be identified.

\section{Discussion}

To our knowledge this is the first study since Blumberg et al. in 1973 [19] and Chandra et al. in 1988 [20] involving the exposure of patients with chronic renal diseases to acute hypobaric hypoxia under controlled conditions. Blumberg exposed six uraemic patients to an altitude of $3450 \mathrm{~m}$ and observed a significant increase in $\mathrm{Fe}$ incorporation when testing their sera in the polycythaemic mouse bioassay. Chandra observed uraemic children during episodes of acute hypoxic stress such as pulmonary oedema, acute haemolysis, heart failure, and hypotension from sepsis and found serum Epo concentrations during these periods were tenfold higher than during steady-state chronic renal failure.

In an earlier experiment (unpublished), we had exposed six controls and 12 patients to an altitude simulating an equivalent of $4000 \mathrm{~m}$ above sea level for $1 \mathrm{~h}$. Disappointingly, in this earlier study we did not observe a significant change of serum Epo, either in healthy controls or in the patients. We drew the conclusion that the degree of stimulation was not sufficient to activate Epo production. We decided therefore to repeat these experiments with a more severe degree of hypoxia. We chose an altitude of $4560 \mathrm{~m}$ above sea level to be sufficient yet tolerable for a prolonged stay of $3.5 \mathrm{~h}$ taking into account the severe anaemia of our patients.

Our present experiment design showed clearly the adequacy of the hypobaric hypoxia stimulus resulting in an increase in Epo by all healthy controls. Therefore this degree of stimulation should be satisfactory to reveal endogenous Epo production in renal failure. The chief finding of our present study is that despite the severity of our chosen stimulus we could not demonstrate stimulation of augmented Epo in circulation after $3.5 \mathrm{~h}$ exposure in our patients.

Since patients with chronic renal failure have similar baseline Epo values and presumably production 
as normal controls, why can the Epo production not be further stimulated as in the controls? These abnorma! findings may lead us to speculate about the actual mechanism of the stimulus of the Epo producing cells. Hypobaric hypoxia creates a reduced oxygen partial pressure in all tissues, causing hyperventilation and respiratory alkalosis. Existing studies on healthy humans and laboratory animals show that hypoxia of the tissue combined with alkalosis are accompanied by Epo stimulation $[12,16]$.

It is well known that in kidney failure, due to bicarbonate loss and a lack of acid excretion, the acid-base status is deranged into metabolic acidosis. We tend to believe that the degree of hyperventilation was not enough to create an alkalotic milieu as in healthy persons, suggesting the necessity of both parameters, tissue hypoxia and alkalosis, to result in adequate stimulation of Epo production. There are certainly other explanations for our findings. From the morphopathological point of view all chronic renal diseases lead to a reduced amount of functional renal tissue, which may explain the lack of Epo production, but maintaining a certain baseline Epo level demonstrated in our study. Evidently, extrarenal production (i.e. in the liver) seems not to be activated, as has been shown in haemodialysis patients suffering from an attack of hepatitis. It also remains unknown to what extent the retention of uraemic substances, especially the intermediate molecules such as hippuric acid, xanthine, and hypoxanthine are responsible for our inability to provoke Epo production. The effect of the immunomodulatory peptides interleukin-l (IL1), tumour necrosis factor- $\alpha$ (TNF- $\alpha$ ) and interferon$\gamma($ IFN- $\gamma)$ on the production of erythropoietin is still unknown [21]. Other researchers [22] have identified the importance of excretory renal function in the regulation of Epo production. They found Epo production to be related to the venous oxygen pressure as an indicator of the renal oxygen supply as well as the renal oxygen consumption. Reduced oxygen consumption caused by acetazolamide, even in the presence of hypobaric hypoxia and a normal acid-base balance, lead to reduced production of Epo.

It is yet to be proven whether a normalized acidbase balance or adequate oxygen-consuming proximal tubular system in renal insufficiency allows a stimulation of endogenous erythropoietin. Despite the findings of the above-mentioned researchers we have gathered evidence to the contrary. With the data and blood samples obtained by Krapf et al [23] we were not ab!e to demonstrate a correlation between the acid-base disturbances and Epo production in two sets of normal subjects, one with a normal acidbase status, the other given ammonium chloride in order to induce metabolic acidosis under the condi- tion of prolonged altitude-induced hypobaric hypoxia.

Our first experiment at $4000 \mathrm{~m}$ above sea level for $1 \mathrm{~h}$ showed no response in normals or patients. Our current experiment at $4560 \mathrm{~m}$ for $3.5 \mathrm{~h}$ showed a response in normals but not in patients. It remains to be shown whether a more severe hypobaric hypoxia than in our present protocol, which means higher than $4560 \mathrm{~m}$ and/or longer than $3.5 \mathrm{~h}$, would be sufficient to stimulate Epo production even in endstage renal disease.

Acknowledgements. We would like very much to thank Mr B. Schenk, Head of Operation of the Hyperbaric Laboratory, University Hospital Zürich, Switzerland, and Mr Baltensberger for technical assistance. We thank Mrs I. Cackett, Nephrology Laboratory, University Hospital Zürich, Switzerland for performing the ELISA. Support from Cilag AG, Schafthausen, Switzerland is appreciated.

\section{References}

1. Carnot $P$, Deflandre C. Sur l'activité hémopoiétique des differents organes au cours de la regénération de sang. $C R$ Acad Sci (Paris) 1906; 143: 432-435

2. Miyake T, Kung C, Goldwasser E. Purification of human erythropoietin. J Biol Chem 1977; 252: 5558-5564

3. Jacobs K. Shoemaker C, Rudersdorf $\mathrm{R}$ et al. Isolation and characterization of genomic c DNA clones of human EPO. Nature 1985; 313: 806-810

4. Koury M, Koury S, Bondurant M, Graber S. Correlation of the molecular and anatomical aspects of renal erythropoietin production. Conirib Nephrol 1989; 76: 24-32

5. Cotes P. Immunoreactive erythropoietin in serum. 1. Evidence for the validity of the assay method and the physiological relevance of estimates. Br J Haematol 1982; 50: 427-438

6. Erslev A, Wilson J, Caro J. Erythropoietin titers in anemic, nonuremic patients. J Lab Clin Med 1987; 109: 429-433

7. Garcia J, Ebbe S, Hollander L, Cutting $\mathrm{H}$ et al. Radioimmunoassay of erythropoietin: circulating levels in normal and polycythemic human beings. J Lab Clin Med 1982; 99: 624-635

8. Caro H, Erslev A. Erythropoietin assays and their use in the study of anemias. Contrib Nephrol 1988; 55: 54-62

9. Abbrecht $P$, Liltell $J$. Plasma erythropoietin in men and mice during acclimatization to different altitudes. $J$ Apply Physiol 1972; 32: 54-58

10. Carmena A. Garcia de Testa N, Frias F. Urinary erythropoietin in men subject to acute hypoxia. Proc Soc Exp Biol Med 1967: 125: 441.443

11. Faura J, Ramos C, Reynafarje E, English E, Finne P, Finch C. Effect of altitude on erythropoiesis. Blood 1969; 33: 668-676

12. Milledge J. Cotes $P$. Serum erythropoietin in humans at high altitude and its relation to plasma renin. $J$ Appl Physiol 1985; 59: 360-364

13. Miller $\mathrm{M}$, Rorth $\mathrm{M}$, Parving $\mathrm{H}$ et al. $\mathrm{pH}$ effect on erythropoietin response to hypoxia. N Engl J Hed 1973; 288: 706-710

14. Reynafarje C, Ramos J, Faura J, Villavicencio D. Humoral control of erythropoietic activity in man during and after altitude exposure. Proc Soc Exp Biol 164: 116: 649-650

15. Siri W, von Dyke D, Winchell H, Pollycoie $M$, Parker $H$, Cleve'and A. Ear'y erytiropoietin, biood and physiological responses to severe hy poxia in man. J Appl Phy'sial :966: 21: 73-80

16. Mairbäueri H, Schobersberger W, Oelz, Bärssch P, Eckhardt $\mathrm{K}$. Bauer $\mathrm{Ch}$. Unchanged in vivo $\mathrm{PSO}$ at high altitude despite decreased red ceil age and elevated 2,3-DPG. J Appl Ph; sial (in revision)

i7. Ecisurdt K, Bouteïier Zi, Kurtz A, Schopen V, Kolier E, Bauer Ch. Rate of erythropoietin formation in humans in 
response to acute hypobaric hypoxia. J Appl Physiol 1989 , 66(4): $1785-1788$

18. Eichenberger A, Binswanger $U$ Validity of enzyme linked immunosorbent assay for erythropoietin (submitted for publication)

19. Blumberg A, Keller H, Mart H. Effect of altitude on erythropiesis and oxygen affinity in anemıc patients on maintenance hemodialysis. Eur J Clin Invest 1973; 3: 93-97

20. Chandra M, Clemons G, McVicar M. Relation of serum erythropoietin levels to renal excretory function: evidence for lowered set point for erythropoietin production in chronic renal fallure. $J$ Pediatr 1988; 113: 1015-1021
21. Jelkman W, Wolff M, Fandrey J. Modulation of the production of erythropoietin by cytokınes: In vitro studies and their clinical implications. Contrib Nephrol 1990; 87: 68-77

22. Eckardt K, Kurtz A, Scholz H, Bauer C. Regulation of EPO Formation in vivo: Does excretory renal function play a role in the endocrne production of EPO? Contrib Nephrol 1989; 76. $33-38$

23. Krapf R, Beeler J, Hertner D, Hulter H. Chronic respiratory alkalosis: The effect of sustained hyperventulation on renal regulation of actd base equilibrium. $N$ Engl J Med 1991, 324: 1394-1401

Received for publicalıon 7.10.91 Accepled in revised form 9.3 .92 